\title{
Application of the 4R nutrient stewardship concept for growing off-season tomatoes in high tunnels
}

\author{
Munir Ahmad ${ }^{1}$, Sahib Alam², Waqar Ahmad ${ }^{3,4}$, Iftikhar Jan $^{2}$, Afia Zia ${ }^{2}$ \\ ${ }^{1}$ Department of Soil and Environmental Sciences, the University of Agriculture Peshawar, KPK 25130, Pakis- \\ tan. ${ }^{2}$ Department of Agricultural Chemistry, the University of Agriculture Peshawar, KPK 25130, Pakistan. \\ ${ }^{3}$ Food and Agriculture Organization of the United Nations, NARC Premises, Park Road, Islamabad, Pakistan. \\ ${ }^{4}$ School of Life and Environmental Sciences, Faculty of Science, The University of Sydney, Eveleigh, NSW \\ 2015, Australia.*Corresponding author:dralam@aup.edu.pk
}

\begin{abstract}
This study aimed to adopt the concept of 4R nutrient stewardship for growing off-season tomatoes in high tunnels. The tomato crop (Hybrid 'Sahel'), grown in high tunnels, was applied with NPK fertilizer at the rate of 80:80:90 kg ha' (after each 15, 30 and 45 days interval) for four months and its effect on tomato yield and quality parameters was investigated. Application of NPK at 15 day intervals resulted in the highest nutritional quality of fruit (NPK uptake $4.32 \mathrm{~kg} \mathrm{~m}^{-2}$, total soluble solids $5.6^{\circ}$ Brix, total acidity $0.43 \%$, protein content $15.31 \%$, $\beta$-carotenes $0.86 \mathrm{mg} 100 \mathrm{~g}^{-1}$, total phenolics $2.34 \mathrm{mg} 100 \mathrm{~g}^{-1}$, total flavonoids $7.14 \mathrm{mg} 100 \mathrm{~g} \mathrm{~g}^{-1}$, antioxidant activity $83.77 \%$ ) and improved shelf-life ( 10 days). However, NPK application at 15 day intervals was not economical in terms of total fertilizer cost incurred and subsequent yield obtained. Application of NPK at 30 day intervals was the most economical (value-cost ratio $>9.0 \mathrm{PKR}$ ) among all application intervals. This study suggested that implementation of the concept of 4Rs i.e., right source, right rate, right placement and right timing of fertilizer application is an effective tool for the production of high quality off-season tomatoes in high tunnels.
\end{abstract}

Keywords: 4R nutrient stewardship, high tunnels, tomatoes, yield, off-season.

\section{Introduction}

The 2030 Agenda for Sustainable Development and the United Nations Decade of Action on Nutrition 2016-2025 calls on all countries and stakeholders to act together to end hunger and prevent all forms of malnutrition by 2030 (FAO, IFAD, UNICEF, WFP and WHO, 2017). Conclusively, achieving nutritious food production for all, has become the greatest challenge ever faced by humanity. The need to secure access to an appropriately nutritious diet, comprising all essential nutrients and water, 
coupled with a sanitary environment and adequate health services to ensure a healthy life for all household members has been defined by the Food and Agriculture Organization (FAO) of United Nations as nutrition security. Hence emphasizing the efficacy of the health component and reflecting the nutritional status of the individual or community in question (FAO, 2017). Contrary to the recent past, nutrition is being considered as an integral part of food security. Accordingly, all four dimensions of food security, viz. the availability, accessibility, utilization, and stability of both macroand micronutrients are deemed components of food security (Hwalla et al., 2016). Subsequent to this, a focus on the role of small producers in the agriculture sector is an important element.

High tunnels are expanding opportunities to increase local food production in the midst of a globalized food system. High tunnel farming techniques are used to produce off-season vegetables such as tomatoes, cucumbers, chilies, sweet peppers, egg plants and gourds. High tunnels have been found to offer many advantages, including environmental modification, season extension, higher yields, quality improvement, crop protection from severe weather and the ability to achieve premium prices compared to open field production (Hemming et al., 2013). Tomatoes (Lycopersicum esculentum Mill.) are one of the most popular and widely cultivated high tunnel vegetables. Tomatoes possess a wide range of vital compounds including water (approximately 90\%), soluble and insoluble solids (5-7\%), citric acid, carotenoids, phenols, flavonoids, vitamins and minerals (Pedro and Ferreira, 2007). Ripe tomatoes have a high content of antioxidants, lycopene and carotene, which play a possible role in the prevention of certain forms of cancer (Story et al., 2010). In Pakistan, tomatoes were cultivated on an area of 626,00 hectares, which produced 587,100 tons tomatoes during 2015-16. During the last two decades the area under tomato cultivation in Pakistan has been increased by 50\% (MNFS \& R 2016). Nonetheless, the ultimate goal is to enhance quality production of tomatoes in high tunnels while improving fertilizer use efficiency and enhancing the socioeconomic status of subsistence-level growers and small land owners.

Nutrient management plays a significant role in enhancing production whether it is applied in open fields or while growing off-season vegetables. Application of nitrogen $(\mathrm{N})$, phosphorus $(\mathrm{P})$ and potassium $(\mathrm{K})$ in the form of organic and inorganic sources at critical growth stages (right time-flowering, fruit setting and fruit development) of the tomato has been reported to enhance their growth and development. For example, $\mathrm{N}$ requirement of tomatoes is moderate during foliage growth, until fruit development. $\mathrm{P}$ is very important for vigorous growth and fruit production. Likewise, $\mathrm{K}$ is needed for fruit development and enlargement (Nasir et al., 2016). However, the United States Department of Agriculture (USDA) together with the Fertilizer Institute promotes a specific framework called $4 \mathrm{R}$ nutrient stewardship (4Rs) that aims at increasing productivity and profitability for growers in both highly intensive agricultural systems and subsistence-level growers. The first 2 Rs, i.e. right source and right rate are commonly followed during crop production in Pakistan. However, the other 2Rs (right time and right place) are reported to be rarely practiced by farming communities, which results in low nutrient use efficiency and low economic returns (FAO, 2017ab).

The objectives of the present study were to assess the suitable time interval (right time) for NPK application on the yield and quality parameters of F1 hybrid "Sahel" tomatoes grown in high tunnels. We hypothesized that both tomato yield and quality-related parameters 
(nutrient uptake, total soluble solids, total acidity, protein content, $\beta$-carotenes, total phenolics, total flavonoids and antioxidant activity) would be equally responsive to the application of NPK at the right rate and the right time of application.

\section{Materials and Methods}

\subsection{Experimental design and study site}

The experiment was conducted in a high tunnel measuring $24 \times 13 \mathrm{~m}$ with $5 \mathrm{~m}$ high gothic arches fitted with a double layer of greenhouse grade, ultraviolettreated polyethylene plastic and $6 \mathrm{ft}$ roll-up sides at the Nuclear Institute for Food and Agriculture (NIFA) Peshawar, Pakistan (longitude $71^{\circ} 50$ and latitude $34^{\circ} 01$ ) in September 2015. The experiment was laid out in a completely randomized design (CRD) and three replications were imposed per treatment. The treatments consisted of different time intervals for the application of NPK to the tomato crop. A nursery of the hybrid tomato cultivar "Sahel" was raised in plastic tubes. After 25 days of germination, the nursery was transferred to a high tunnel. The soil of the experimental high tunnel bed was clay loamy, alkaline in nature and non-saline. The soil was marginal in terms of the contents of organic matter (OM), P, K and adequate with respect to zinc ( $\mathrm{Zn})$ concentration (Table 1). We maintained a distance of 1.5 and $2.5 \mathrm{ft}$ between plants and rows, respectively. NPK was applied at the rate of 80:80:90 kg $\mathrm{ha}^{-1}$ to the crop after each 15 (T1), 30 (T2) and 45 (T3) days of transplantation for four months. Based on previous related studies with high tunnel tomato production, $80: 80: 90 \mathrm{~kg} \mathrm{ha}^{-1} \mathrm{NPK}$ was assumed to be the right rate during the entire growth period of four months. The control treatment $\left(\mathrm{T}_{0}\right)$ was kept without any NPK application. Application of $\mathrm{Zn}$ to the entire field was at the rate of 5 $\mathrm{kg} \mathrm{ha}^{-1}$ as a basal dose after the establishment of the crop. The experiment was properly maintained following standard cultural practices as commonly observed in high tunnel farming.

\subsection{Tomato yield}

Mature tomato fruits in each treatment were collected at each harvest and weighed in kilograms. The total yield per treatment was calculated by adding the yields at all harvests for the same treatment.

Table 1. Physiochemical properties of soil before transplantation

\begin{tabular}{|c|c|c|c|}
\hline Physiochemical properties & $0-15 \mathrm{~cm}$ & $16-30 \mathrm{~cm}$ & Mean \\
\hline $\mathrm{pH}$ & 8.20 & 8.30 & 8.25 \\
\hline Electrical conductivity $\left(\mathrm{ds} \mathrm{m}^{-1}\right)$ & 0.90 & 0.85 & 0.87 \\
\hline Organic matter $(\%)$ & 0.92 & 0.57 & 0.74 \\
\hline Nitrogen (\%) & 0.069 & 0.058 & 0.06 \\
\hline Phosphorus (ppm) & 8.12 & 6.25 & 7.18 \\
\hline Potassium (ppm) & 150.0 & 130.0 & 140.0 \\
\hline Zinc (ppm) & 1.40 & 1.00 & 1.20 \\
\hline Lime content (\%) & 21.75 & 21.25 & 21.50 \\
\hline Soil texture & & Clay loam. & \\
\hline
\end{tabular}




\subsection{Tomato yield}

Mature tomato fruits in each treatment were collected at each harvest and weighed in kilograms. The total yield per treatment was calculated by adding the yields at all harvests for the same treatment.

\subsection{Carpometric characteristics}

Fresh ripe fruits $(\mathrm{n}=10)$ were randomly collected at maturity from the third harvest in each replication and evaluated for different physico-chemical parameters. The fruit weight was recorded by an electronic balance with a sensitivity of $0.01 \mathrm{~g}$ and the fruit density was measured by the method of Jahromi et al., (2008). The polar and equatorial diameters of the fruits were measured with digital slide calipers (Chattopadhyay et al., 2013). Total soluble solids ( $\left.{ }^{\circ} \mathrm{Brix}\right), \mathrm{pH}$ and total acidity were determined by the methods of AOAC (2016).

\subsection{Chemical analysis and antioxidant activity of the tomato fruits}

The protein and moisture contents of the tomato fruits were determined by standard protocols of AOAC (2016). The $\mathrm{K}$ and $\mathrm{Zn}$ concentrations of the fruits were assessed by atomic absorption spectrophotometer, $\mathrm{P}$ by UV-visible spectrophotometer and $\mathrm{N}$ by Kjeldahl apparatus (Elbadrawy and Sello, 2016). The vitamin C con-

$$
\mathrm{VCR}=\frac{\text { Value of increased crop output }}{\text { Total cost of fertilizer applied }}
$$

tent of the fruits was determined by the method modified from Mahmud et al., (2010). The total phenolic contents and flavonoids were assessed by the methods of Luthria et al., (2006). The $\beta$-carotene content was estimated by the method of Howe and Sherry (2006) and the antioxidant activity by Ahmad et al., (2010).

\subsection{Calculation of Value-Cost Ratio (VCR)}

The value-cost ratio of NPK application at different intervals of time was calculated by dividing the value of increased crop output on the total cost of fertilizer applied as presented by the following formula:

\subsection{Statistical analysis}

The data obtained was subjected to analysis of variance (ANOVA) according to completely randomized design (CRD) using the statistical software package Statistix version 8.1. Means were separated by least significant difference (LSD) test at $0.05 \%$ level of probability.

\section{Results}

The application of NPK fertilizers at different time intervals significantly $(p<0.05)$ affected the tomato yield, fruit weight and fruit size in terms of polar and equatorial diameters, whereas no significant effect was noted on the density of the tomato fruits (Table 2). The highest marketable yield $\left(12.21 \mathrm{~kg} \mathrm{~m}^{-2}\right)$, individual fruit weight $(160.0 \mathrm{~g})$ and polar and equatorial diameters (7.50 and 5.51 $\mathrm{cm}$, respectively) of the fruits were recorded for $\mathrm{T}_{2}$ where NPK at the rate of 80:80:90 $\mathrm{kg} \mathrm{ha}^{-1}$ was applied after each 30 days of transplantation during the cropping period. The fruit density and moisture 
Table 2. Effect of time interval of NPK application on the yield, density, moisture, chlorophyll content and shelf life of tomato under high tunnel cropping system

\begin{tabular}{lcccccc}
\hline Treatments $^{*}$ & $\begin{array}{c}\text { Yield } \\
\left(\mathrm{Kg} \mathrm{m}^{-2}\right)\end{array}$ & $\begin{array}{c}\text { Fruit weight } \\
(\mathrm{g})\end{array}$ & $\begin{array}{c}\text { Density } \\
\left(\mathrm{g} \mathrm{cm}^{-3}\right)\end{array}$ & $\begin{array}{c}\text { Moisture } \\
(\%)\end{array}$ & $\begin{array}{c}\text { Chlorophyll (SPAD } \\
\text { value) }\end{array}$ & Shelf life (Days) \\
\hline $\mathrm{T}_{0}$ & $3.78 \mathrm{~d}$ & $50.0 \mathrm{~d}$ & $0.98 \mathrm{a}$ & $94.60 \mathrm{a}$ & $47.28 \mathrm{~b}$ & $8.0 \mathrm{ab}$ \\
$\mathrm{T}_{1}$ & $11.18 \mathrm{~b}$ & $147.0 \mathrm{~b}$ & $1.0 \mathrm{a}$ & $92.15 \mathrm{a}$ & $57.63 \mathrm{a}$ & $9.0 \mathrm{a}$ \\
$\mathrm{T}_{2}$ & $12.21 \mathrm{a}$ & $160.0 \mathrm{a}$ & $1.10 \mathrm{a}$ & $92.65 \mathrm{a}$ & $56.43 \mathrm{a}$ & $9.0 \mathrm{a}$ \\
$\mathrm{T}_{3}$ & $9.29 \mathrm{c}$ & $115.0 \mathrm{c}$ & $0.99 \mathrm{a}$ & $93.30 \mathrm{a}$ & $53.54 \mathrm{a}$ & $9.0 \mathrm{a}$ \\
\hline
\end{tabular}

Values in each column followed by similar letters are not significantly different at $\mathrm{P} \leq 0.05$. ${ }^{*} \mathrm{~T}_{0}=\mathrm{Control}$ (without $\mathrm{NPK}$ ); $\mathrm{T} 1=$ NPK application after each 15 days; T2 = NPK application after each 30 days; T3 = NPK application after each 45 days

content did not significantly $(p>0.05)$ differ from the control treatment.

The data pertaining to $\mathrm{pH}$, total soluble solids (TSS) and protein content indicated that variations in the application time of NPK significantly $(p<0.05)$ influenced these parameters. However, the impact of temporal variation in NPK application was non-significant $(\mathrm{p}>0.05)$ on the total acidity of the tomato fruits (Table 4). The $\mathrm{pH}$ was found to be highest (4.50) for control treatment and lowest for $\mathrm{T}_{2}$ (3.90). The highest total soluble solid (5. $6^{\circ}$ Brix), total acidity $(0.43 \%)$ and protein content $(15.31 \%)$ was observed in $\mathrm{T}_{1}$ when the crop was supplied with NPK fertilizer at 15 day intervals after transplantation.

The mineral content of the tomato fruits and NPK uptake by tomato plants as affected by fertilizer application at different time intervals was depicted in Table 3. The highest N (2.45\%), P (0.41\%), K (3.40\%) and Zn $\left(23 \mathrm{mg} \mathrm{kg}^{-1}\right.$ ) content in the tomato fruits was recorded when the crop was frequently applied with NPK after each 15 day interval i.e. $T_{1}$. The mean total NPK uptake by the tomato plants was found highest in $\mathrm{T}_{1}(4.32 \mathrm{~kg}$ $\left.\mathrm{m}^{-1}\right)$ followed by $\mathrm{T}_{2}\left(4.06 \mathrm{~kg} \mathrm{~m}^{-1}\right)$ whereas the control treatment $\left(\mathrm{T}_{0}\right)$ showed the lowest level $\left(0.75 \mathrm{~kg} \mathrm{~m}^{-2}\right)$ of NPK uptake.

Table 4. Effect of time interval of NPK application on the nutritional quality and antioxidant activity of tomato under high tunnel farming system.

\begin{tabular}{|c|c|c|c|c|c|c|c|c|c|}
\hline Treatments & $\mathrm{pH}$ & $\begin{array}{c}\text { TSS } \\
\left({ }^{0} \text { Brix }\right)\end{array}$ & $\begin{array}{c}\text { Total Acidity } \\
(\%)\end{array}$ & $\begin{array}{c}\text { Protein } \\
(\%)\end{array}$ & $\begin{array}{l}\text { Vitamin C } \\
\left(\mathrm{mg} 100 \mathrm{~g}^{-1}\right)\end{array}$ & $\begin{array}{l}\beta \text {-Carotene } \\
\left(\mathrm{mg} 100 \mathrm{~g}^{-1}\right)\end{array}$ & $\begin{array}{l}\text { Total Phenolics } \\
\left(\mathrm{mg} 100 \mathrm{~g}^{-1}\right)\end{array}$ & $\begin{array}{l}\text { Total Flavonoids } \\
\qquad\left(\mathrm{mg} 100 \mathrm{~g}^{-1}\right)\end{array}$ & $\begin{array}{c}\text { Antioxidant } \\
\text { Activity } \\
(\%)\end{array}$ \\
\hline $\mathrm{T}_{0}$ & $4.5 \mathrm{a}$ & $4.8 \mathrm{~b}$ & $0.35 \mathrm{a}$ & $9.0 \mathrm{c}$ & $17.36 \mathrm{c}$ & $0.53 b$ & $1.09 \mathrm{c}$ & $4.14 \mathrm{c}$ & $72.16 \mathrm{~b}$ \\
\hline $\mathrm{T}_{1}$ & $4.8 \mathrm{~b}$ & $5.6 \mathrm{a}$ & $0.43 a$ & $15.31 \mathrm{a}$ & $18.61 \mathrm{c}$ & $0.86 \mathrm{a}$ & $2.34 \mathrm{a}$ & $7.14 \mathrm{a}$ & $83.77 \mathrm{a}$ \\
\hline $\mathrm{T}_{2}$ & $3.9 \mathrm{bc}$ & $5.3 \mathrm{a}$ & $0.41 \mathrm{a}$ & $13.87 \mathrm{~b}$ & $24.33 b$ & $0.75 \mathrm{a}$ & $2.2 \mathrm{a}$ & $6.45 a$ & $83.27 \mathrm{a}$ \\
\hline $\mathrm{T}_{3}$ & $4.2 \mathrm{ab}$ & $4.9 \mathrm{~b}$ & $0.37 \mathrm{a}$ & $14.31 \mathrm{ab}$ & $29.94 \mathrm{a}$ & $0.60 \mathrm{~b}$ & $1.95 \mathrm{~b}$ & $5.35 \mathrm{~b}$ & $80.50 \mathrm{a}$ \\
\hline
\end{tabular}

Values in each column followed by similar letters are not significantly different at $\mathrm{P} \leq 0.05$. ${ }^{*} \mathrm{~T}_{0}=\mathrm{Control}$ (without $\mathrm{NPK}$ ); $\mathrm{T} 1=$ NPK application after each 15 days; T2 = NPK application after each 30 days; T3 = NPK application after each 45 days 
Table 3. Effect of time interval of NPK application on the N, P, K and Zn content and total NPK uptake of tomato plants under high tunnel farming system.

\begin{tabular}{|c|c|c|c|c|c|c|c|c|c|}
\hline \multirow[b]{2}{*}{ Treatments } & \multicolumn{4}{|c|}{ Mineral contents of fruit } & \multicolumn{4}{|c|}{ Mineral contents of straw } & \multirow{2}{*}{$\begin{array}{c}\text { Total NPK } \\
\text { uptake } \\
\left(\mathrm{Kg} \mathrm{m}^{-2}\right)\end{array}$} \\
\hline & $\mathrm{N}(\%)$ & $\mathrm{P}(\%)$ & $\mathrm{K}(\%)$ & $\mathrm{Zn}\left(\mathrm{mg} \mathrm{kg}^{-1}\right)$ & N (\%) & $\mathrm{P}(\%)$ & $\mathrm{K}(\%)$ & $\mathrm{Zn}\left(\mathrm{mg} \mathrm{kg}^{-1}\right)$ & \\
\hline $\mathrm{T}_{0}$ & $1.44 \mathrm{c}$ & $0.20 \mathrm{~b}$ & $2.5 \mathrm{c}$ & $21 \mathrm{a}$ & $1.62 \mathrm{c}$ & $0.11 \mathrm{~b}$ & $1.11 \mathrm{c}$ & $25 \mathrm{c}$ & $0.75 \mathrm{~d}$ \\
\hline $\mathrm{T}_{1}$ & $2.45 \mathrm{a}$ & $0.41 \mathrm{a}$ & $3.40 \mathrm{a}$ & $23 \mathrm{a}$ & $1.90 \mathrm{a}$ & $0.19 \mathrm{a}$ & $1.31 \mathrm{~b}$ & $42.0 \mathrm{a}$ & $4.32 \mathrm{a}$ \\
\hline $\mathrm{T}_{2}$ & $2.22 \mathrm{~b}$ & $0.37 \mathrm{a}$ & $3.2 \mathrm{ab}$ & $22 \mathrm{a}$ & $1.84 \mathrm{ab}$ & $0.20 \mathrm{a}$ & $1.46 \mathrm{a}$ & $34 b$ & $4.06 \mathrm{~b}$ \\
\hline $\mathrm{T}_{3}$ & $2.29 \mathrm{ab}$ & $0.36 \mathrm{a}$ & $2.7 \mathrm{bc}$ & $22 \mathrm{a}$ & $1.74 b c$ & $0.18 \mathrm{a}$ & $1.20 \mathrm{bc}$ & $38 \mathrm{ab}$ & $2.82 \mathrm{c}$ \\
\hline
\end{tabular}

Values in each column followed by similar letters are not significantly different at $\mathrm{P} \leq 0.05$. ${ }^{*} \mathrm{~T}_{0}=$ Control (without $\mathrm{NPK}$ ); $\mathrm{T} 1=$ NPK application after each 15 days; T2 = NPK application after each 30 days; T3 = NPK application after each 45 days

The antioxidant compounds such as vitamin $\mathrm{C}$ (ascorbic acid), $\beta$-carotene, total phenolics and flavonoids and the antioxidant activity of the tomato fruits was also significantly $(p<0.05)$ affected by variations in the application time of NPK after transplantation of the tomato crop (Table 4). The highest $\beta$-carotene $\left(0.86 \mathrm{mg} 100^{-1} \mathrm{~g}\right)$, total phenolics $\left(2.34 \mathrm{mg} 100^{-1} \mathrm{~g}\right)$,

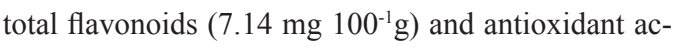
tivity $(83 \%)$ was observed for $\mathrm{T}_{1}$ whereas vitamin $\mathrm{C}$ concentration was highest $\left(29.94 \mathrm{mg} 100^{-1} \mathrm{~g}\right)$ in fruit obtained from $\mathrm{T}_{3}$. From the data it was observed that application of NPK fertilizer after each 15 days of time interval had a promising impact on the majority of antioxidant compounds and antioxidative activity of the tomato crop in high tunnel farming.

The moisture content of the tomato fruits ranged from $92.15 \%$ in $\mathrm{T}_{1}$ to $94.60 \%$ in control treatment (Table 2). However, the effect of NPK application time variation was non-significant $(p>0.05)$ on the moisture content of the fruits. The data regarding the storage life of the fruits indicated that the longest shelf life of 10 days was exhibited by fruits from $T_{1}$ whereas the shortest shelf life (8.0 days) was recorded for the control treatment.

The value cost ratio (VCR) of NPK application to tomato F1 hybrid "Sahel" at different intervals of time in the high tunnel cropping system revealed that it ranged from 3.73 to 9.16 (Table 5). The highest VCR value was recorded for $\mathrm{T}_{2}$ followed by $\mathrm{T}_{3}$. VCR for all treatments was more than 2.0 , showing satisfactory risk coverage against investment in the use of fertilizers. The data also indicated that NPK application after each 30 days interval proved better whereas application of NPK at 15 day intervals was not economical, as was clear from the least VCR value.

\section{Discussion}

\subsection{Tomato yield and related parameters}

Achieving nutritious food production for all is a challenging task and the ultimate objective of applying the concept of $4 \mathrm{Rs}$ is to improve the yield and nutritive value of the produce. The $4 \mathrm{R}$ approach on nutrient management is linked with various aspects of agricultural production systems and value chains (Figure 1). The 4R nutrient stewardship is an integral part of best management practices. Right source matches nutrient type to crop needs; Right rate matches the amount of nutrients to the crop need and depends on soil and water analyses and crop and soil fertility status; Right time involves making nutrients available when the crop needs them and is correlated with crop responsive growth stages; Right place encompasses keeping nutrients where crops can use them and is associated with 
Table 5. The value-cost-ratio of NPK application at various time interval for growing off-season tomato in high tunnel.

\begin{tabular}{|c|c|c|c|c|c|}
\hline Treatment & Total Yield (kg) & Gross Return (Rs) & $\begin{array}{c}\text { Fertilizer Application } \\
\text { Cost (Rs) }\end{array}$ & $\begin{array}{c}\text { Net Return } \\
\text { (Rs) }\end{array}$ & $\mathrm{VCR}$ \\
\hline $\mathrm{T}_{0}$ & 118 & 4720 & -- & 4720 & -- \\
\hline $\mathrm{T}_{1}$ & 349 & 13960 & 1955 & 12005 & 3.73 \\
\hline $\mathrm{T}_{2}$ & 381 & 15240 & 1035 & 14205 & 9.16 \\
\hline $\mathrm{T}_{3}$ & 290 & 11600 & 725 & 10875 & 8.49 \\
\hline
\end{tabular}

using the best method which shows higher nutrient use efficiency and/or minimal loss (FAO, 2017ab). The present study evaluated the frequency and suitable NPK application time for the tomato hybrid cultivar "Sahel" under a high tunnel farming system to obtain potential yield and better quality produce during the off-season cropping of tomatoes. Significant variations existed among the fruit weights, fruit sizes, in terms of polar and equatorial diameters and yield of the tomato crop with respect to NPK application at different time intervals after transplantation. While the fruit density was not significantly influenced by the temporal variation in NPK application; the higher yield and better tomato weights and sizes were obtained when the crop was frequently fertilized at short intervals of time. These observations supported the fact that tomatoes are a high nutrient exhaustive crop and need frequent fertilizer applications (Sepat et al., 2012). In earlier research, it was reported that a combination of NP fertilizer at the rate of 110:120 $\mathrm{kg} \mathrm{ha}^{-1}$ gave maximum yield as compared to other treatments (Balemi et al., 2008). Fandi et al., (2010) reported that application of high level of NPK fertilizers increased tomato fruit weight which in turn gave maximum yield. Our values regarding individual fruit weight, fruit density and size are fairly in line with those reported in previous literature (Chattopadhyay et al., 2013). The more frequent application of NPK fertilizer at short in- tervals of time considerably improved the number, size, density and yield of fruits per plant.

\subsection{Temporal variation in NPK application, carpometric characteristics and protein content}

Total soluble solids, $\mathrm{pH}$ and total acidity are the key quality attributes that contribute towards the processing and storage stability of tomatoes. Among the NPK treatments, the application at 15 day intervals resulted in the closest recommended values of these parameters in the tomato fruits. A high TSS value is desirable for improved nutritional and processing implications. Similarly, a high titratable acidity value is an important stability indicator for extended shelf life during storage. It has been reported that a minimum value of $0.40 \%$ acidity is required to suppress the growth of lactic acid-forming bacterial species like Bacillus coagulans in the processed tomatoes (Chattopadhyay et al., 2013). In addition, the acidity of the fruit also contributes towards the flavor of tomato products. Tomatoes are high acid food and thus require less drastic thermal treatments than foods classified as low acid $(\mathrm{pH}>4.6)$ for the eradication of spoilage microorganisms to ensure food safety. It has been suggested that $\mathrm{pH} 4.4$ is the maximum desirable for safety and the optimum target $\mathrm{pH}$ should be 4.25 (Anthon et al, 2011). The previous literature reported 


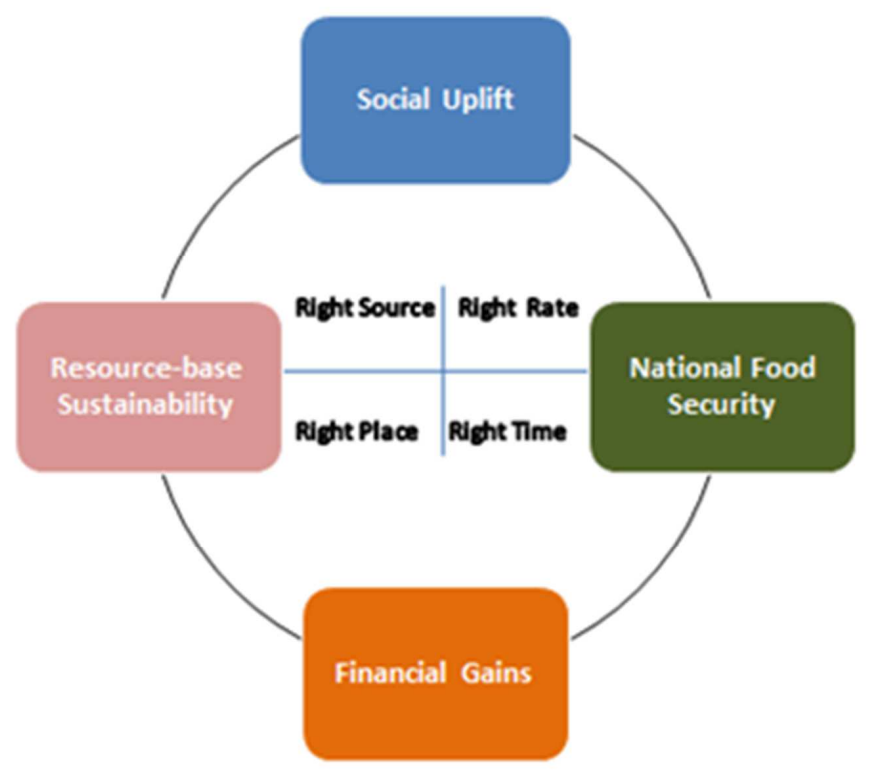

Figure 1. Potential linkages of 4R nutrient stewardship with different aspects of agricultural production systems and value chains. Source: adopted from FAO $(2017 a, b)$.

that the $\mathrm{pH}$ of tomato fruits ranged from 3.70 to 5.40 (Rai et al., 2012) and TSS 4.9 to $5.5^{\circ}$ Brix (Naz et al., 2011). In the present study, the values of TSS (5.60\%), total acidity $(0.43 \%)$ and $\mathrm{pH}(4.23)$ achieved for NPK application at 15 day intervals are fairly in line with the values recommended in previous studies. Application of NPK at shorter intervals of time might have enhanced the absorption and translocation of various metabolites including the acids, minerals and carbohydrates, which contributed towards the acidity and TSS of the fruit. During ripening of the fruits, the carbohydrate reserves of the roots and stem are drawn upon heavily and hydrolyzed into sugars.

Adequate availability of nutrients in the soil enhances their acquisition and uptake by plants and subsequent conversion into plant metabolites.
This phenomenon is specifically accelerated during the ripening stage of the tomato fruits (Sepat et al., 2012).

The protein content of the tomato fruits ranged from 9.00 to $15.31 \%$ and the highest value was achieved when the crop was fertilized at 15 day intervals after transplantation until the final harvest of the crop. The values were significantly lower in the control treatment and in the crop that was fertilized at 30 day intervals. Generally, tomatoes are not a good source of protein, but hybrid cultivars containing protein up to 12\% have been reported (Fuentes et al., 2013). The higher content of protein in the tomato fruits, in the present study, was due to the consistent supply of nitrogen which is a key component for protein biosynthesis. Our results regarding higher protein content are fairly supported by the 'C/N balance theory'. The 
theory explains that when $\mathrm{N}$ is consistently available, plants will make compounds with high $\mathrm{N}$ contents such as protein. However, with a limited supply of N, plant metabolism changes more toward C-containing compounds such as starches, cellulose and ascorbic acid etc.

\subsection{Dynamics of nutrient uptake and mineral concentration of tomatoes}

It was observed in the present study that NPK uptake was enhanced when the crop was supplied with fertilizer at 15 day intervals followed by fertilizer application after each 30 days. This might be due to the fact that the plants needed more nutrients during the early stages of growth for the development of roots, shoots and flowering. It has been reported that $\mathrm{N}, \mathrm{P}$ and $\mathrm{K}$ are the essential constituents of proteins, chlorophyll, xylum sap and other compounds along with their contribution in many other compounds of physiological importance in plants (Gallegos-Cedillo et al., 2016). Hence, the application of NPK fertilizer at earlier growth stages along with subsequent applications at short intervals of time might be responsible for the increased synthesis of plant growth hormones, development of extensive root systems and therefore high nutrient utilization by the tomato plants (Ayeni, 2010). Likewise, tomatoes need a high amount of $P$ at early stages of growth, but its $\mathrm{K}$ need is relatively constant throughout the crop cycle. However, the need for $\mathrm{N}$ take-up becomes more vigorous during the vegetative and fruiting stage. Thus, a frequent supply of nutrients enhanced the nutrient concentration of the tomato fruits as well as the total NPK uptake by the plant. It was observed that NPK uptake linearly decreased with extended fertilizer application times. The blooming stage of tomatoes started about 5 weeks after transplantation. From the blooming stage to harvest, more nutrients were needed which were com- pensated by frequent application of NPK with time. The application of adequate amounts of nutrients positively affected plant quality characteristics, improved total yield and reduced the chances of disease attacks (Hernández-Montiel et al., 2017). The better uptake of nutrients such as N, P, K and $\mathrm{Zn}$ increased the plant development and the quantity of marketable tomato fruits (Al-Ismaily et al., 2014).

\subsection{Temporal variations in NPK application and antioxidant components of tomato fruits}

The antioxidant components such as vitamin $\mathrm{C}$, $\beta$-carotene, total phenolics and total flavonoids and the antioxidant activity of the tomato fruits were also significantly affected by NPK application based on time. $\beta$-carotene, total phenolics and flavonoids showed the highest values when the tomatoes were fertilized at 15 day intervals whereas vitamin $\mathrm{C}$ exhibited the highest value at 45 days fertilization. The higher concentration of these compounds in the tomato fruits, nourished with frequent NPK application, could be due to the fact that the soil contained a sufficient supply of basic nutrients for the synthesis of vital chemical compounds by the plants. The available literature reports that the concentration of antioxidant compounds in tomato fruits is significantly influenced by fertilizers (Toor et al., 2006). Our results regarding similar values reported in previous literature for $\beta$-carotene, total phenolics and total flavonoids content are fairly supported by the fact that plants efficiently synthesized these compounds with a consistent and adequate availability of NPK to the crop (Toor et al., 2006; Hdider et al., 2013). However, a reversal pattern for vitamin $\mathrm{C}$ content was observed, whose production was enhanced at delayed NPK applications. The antioxidant activity of tomato fruits nourished with NPK fertilizer also significantly varied from the control treatment. However, the fre- 
quency and time interval for NPK application did not significantly affect the antioxidant activity of the tomato fruits. The antioxidant activity is determined by a large number of secondary metabolites present in tomatoes. Therefore, attention has been given to such compounds which exhibit prominent antioxidant activity and increase the nutritional characteristics of food. The present research finds supportive evidence from the study of Kotikova et al., (2011) who reported $83 \%$ hydrophilic antioxidant activity.

\subsection{Temporal variations in NPK application, moisture content and shelf-life}

The present study revealed that variation in time for NPK application did not significantly influence the moisture content of the tomato fruits. Nevertheless, the shelf life of the fruit was significantly affected. The longest shelf life of 10 days was shown by tomato fruits when the plants received NPK fertilizer after each 15 days of transplantation, whereas the shortest shelf life was exhibited by fruits obtained from control plots ( 8.00 days) and the plots ( 8.33 days) that received fertilizer after each 45 days of transplantation. Plant nutrition is one of the key pre-harvest factors that influence the post-harvest quality of tomato fruits (Nyamah et al., 2012). Both the quantity and type of fertilizer used during production affects the post-harvest quality of tomato fruits. For instance, K plays a vital role in maintaining the shelf life of tomato fruits (Constan-Aguilar et al., 2014). A timely supply of K during tomato production prevents yellow shoulder and enhances the color and titratable acidity of tomato fruits during storage (Hartz et al., 2005). The extended period of shelf life of NPK applied tomato fruits, in our case, might be due to the consistent and timely application of $\mathrm{K}$ as compared to the control (Etminan et al., 2004).

\subsection{Value cost ratio of the tomato crop}

Value cost ratio is an important criterion which is related to the economics of the commodity produced and determines the net profit for the farmer. In this study, different values of VCR were calculated with the addition of NPK fertilizer to the crop at different intervals of time. The highest VCR of 9.16 was achieved when the fertilizer was applied after each 30 days to the crop. The lowest VCR value was recorded when the fertilizer was applied to the crop after 15 day intervals indicating that unnecessary application of frequent fertilizer doses, giving a marginal yield increase, was neither economical nor profitable. It is thus beneficial to use the costly fertilizer inputs at judicious levels to earn more profit.

\section{Conclusions}

The application of NPK at the rate of 80:80:90 $\mathrm{kg} \mathrm{ha}^{-1}$ to F1 hybrid "Sahel" tomatoes in high tunnels at 15 day intervals during off-season production, resulted in the highest nutritional quality of fruit and improved shelf-life. However, 15 days interval application of NPK was not economical in terms of total fertilizer cost incurred and subsequent yield obtained. NPK application at 30 day intervals was found to be the most economical. Further studies are required on a range of soils in experimental high tunnel beds in order to improve our understanding of how the application of NPK at different rates of nutrients relates to the fertility status of the high tunnel beds and how it affects the response of tomato plants in terms of production, quality and economics.

\section{Acknowledgements}

We are grateful to the Director Nuclear Institute for Food and Agriculture (NIFA), Peshawar for allowing 
us to conduct the experiment in the premises of the institute. We also acknowledge the support provided by the United States Department of Agriculture for FAO's Projects Reference, GCP/PAK/130/USA and GCP/PAK/143/USA "Soil Fertility Management for Sustainable Intensification in Pakistan: Baseline Input Atlas and Promotion of Soil Fertility with Private Sector", and "4R Nutrient Stewardship for Sustainable Agriculture Intensification in Pakistan: Baseline Input Atlas and Promotion of Best Soil Management Practices". The extension mechanism adopted in these projects through public-private partnership helped to design this study and focus on $4 \mathrm{R}$ nutrient stewardship. The authors are highly grateful to Mrs Anthea Brown - Membership Secretary and Treasurer - Society for Environmental Geochemistry and Health (BGS retired) for her valuable suggestions in improving this manuscript.

\section{References}

Ahmad, N., Fazal, H., Abbasi, B.H., Rashid, M., Mahmood, T., Fatima, N. 2010. Efficient regeneration and antioxidant potential in regenerated-tissues of Piper nigrum L. Plant Cell Tissue Org. Cult. 102, 129-134.

Al-Ismaily, S.S., Al-Yahyai, R.A., Al-Rawahy, S.A. 2014. Mixed fertilizer can improve fruit yield and quality of field-grown tomatoes irrigated with saline water. J. Plant Nutr. 37, 1981-1996.

Anthon, G.E., LeStrange, M., Barrett, D.M. 2011. Changes in $\mathrm{pH}$, acids, sugars and other quality parameters during extended vine holding of ripe processing tomatoes. J. Sci. Food Agric. 91, 11751181.

AOAC (Association of Official Analytical Chemists). 2016. Official methods of analysis of the Association of Official Analytical Chemists $18^{\text {th }}$ ed Arlington, VA, USA.
Ayeni, L.S. 2010. Effect of cocoa pod ash, NPK fertilizer and their combinations on soil chemical properties and yield of tomato (Lycopersicon esculentum) on two soil types. New York Sci. J. 3, 1-10.

Balemi, T. 2008. Response of tomato cultivars differing in growth habit to nitrogen and phosphorus fertilizers and spacing on vertisol in Ethiopia. Acta. Agric. Slovenica. 91, 103-119.

Chattopadhyay, A., Chakraborty, I.V.I., Siddique, W. 2013. Characterization of determinate tomato hybrids: search for better processing qualities. J. Food Process. Tech. 4, 01-06.

Constan-Aguilar, C., Leyva, R., Romero, L., Soriano, T., Ruiz, J.M. 2014. Implication of potassium on the quality of cherry tomato fruits after postharvest during cold storage. Int. J. Food Sci. Nutr. 65, 203-211.

Elbadrawy, E., Sello, A. 2016. Evaluation of nutritional value and antioxidant activity of tomato peel extracts. Arab. J. Chem. 9, 1010-1018.

Etminan, M., Takkouche, B., Caamano, F. 2004. The role of tomato products and lycopene in the prevention of prostate cancer: a meta-analysis of observational studies. Cancer Epidemiol. Biomarkers Prev. 13, 340- 345.

Fandi, M., Muhtaseb, J., Hussein, M. 2010. Effect of $\mathrm{N}, \mathrm{P}, \mathrm{K}$ concentrations on yield and fruit quality of tomato (Solanum lycopersicumL.) in tuff culture. J. Cent. Eur. Agric. 11, 179-184.

FAO (Food and Agriculture Organization) of the United Nations. 2017a. Soil Fertility Atlas of Pakistan: The Punjab Province. Ahmad, W., Niino, Y., Zia, M.H., Mahmood, K., Ashraf, A., Ahmad, N., Salim, M., Shakir, M.A. (Eds.), ISBN 978-9698304-08-9. Islamabad, Pakistan, p 115.

FAO (Food and Agriculture Organization) of the United Nations. 2017b. Soil Fertility Atlas of Pakistan: The Sindh Province. Ahmad, W., Niino, Y., Zia, M.H., Mahmood, K., Ashraf, A., Memon, 
K.S., Shah, Z.H., Aslam, M., Ahmad, N., Salim, M., Shakir, M.A. (Eds.), ISBN 978-969-8304-096. Islamabad, Pakistan, p 105.

FAO, IFAD, UNICEF, WFP and WHO. 2017. The State of Food Security and Nutrition in the World 2017. Building resilience for peace and food security. ISBN 978-92-5-109888-2 Italy Rome, p 117.

Fuentes, E., Carle, R., Astudillo, L., Guzmán, L., Gutiérrez, M., Carrasco, G., Palomo, I. 2013. Antioxidant and antiplatelet activities in extracts from green and fully ripe tomato fruits (Solanum lycopersicum) and pomace from industrial tomato processing. Evid. Based Complement. Alternat. Med. 2013, 867578.

Gallegos-Cedillo, V.M., Urrestarazu, M., Álvaro, J.E. 2016. Influence of salinity on transport of Nitrates and Potassium by means of the xylem sap content between roots and shoots in young tomato plants. J. Soil Sci. Plant Nutr. 16, 991-998.

Hartz, T.K., Johnson, P.R., Francis, D.M., Miyao, E.M. 2005. Processing tomato yield and fruit quality improved with potassium fertigation. Hort. Sci. 40, 1862-1867.

Hdider, C., Ilahy, R., Tlili, I., Lenucci, M.S., Dalessandro, G. 2013. Effect of the stage of maturity on the antioxidant content and antioxidant activity of high-pigment tomato cultivars grown in Italy. Food. 7, 1-7.

Hemming, S., Mohammadkhani, V., Ruijven, J.V. 2013. Technology of diffuse greenhouse covering materials-influence on light transmission, light scattering and light spectrum. ISHS. Acta. Hort. $1037,883-895$.

Hernández-Montiel，L.G., Chiquito-Contreras，C.J, Murillo-Amador, B., Vidal-Hernández, L., Qui-
ñones-Aguilar, E.E., Chiquito-Contreras, R.G. 2017. Efficiency of two inoculation methods of Pseudomonas putida on growth and yield of tomato plants. J. Soil Sci. Plant Nutr. 17, 10031012.

Howe, A.J., Sherry, A.T. 2006. Evaluation of analytical methods for carotenoid extraction from biofortified maize (Zea mays spp). J. Agric. Food Chem. 54, 7992-7997.

Hwalla, N., Labban, S.E., Bahn, R.A. 2016. Nutrition security is an integral component of food security. Front. Life Sci. 9, 167-172.

Jahromi, M.K., Mohtasebi, S.S., Jafari, A., Mirasheh, R., Rafiee, S. 2008. Determination of some physical properties of date fruit (cv. Mazafati). J. Agric. Tech. 4, 1-9.

Kotikova, Z., Lachman, J., Hejtmankova, A., Hejtmankova, K. 2011. Determination of antioxidant activity and antioxidant content in tomato varieties and evaluation of mutual interactions between antioxidants. Food Sci. Tech. 44, 1703-1710.

Luthria, D.L., Mukhopadhyay, S., Krizek, D.T. 2006. Content of total phenolics and phenolic acids in tomato (Lycopersicon esculentum Mill.) fruits as influenced by cultivar and solar UV radiation. J. Food Comp. Anal. 19, 771-777.

Mahmud, T.M.M., Al-Eryysni-Raqeeb, A., Omer, S.R.S., Zaki, A.R.M., Al-Eryani, A.R. 2008. Effect of different concentrations and application of calcium on storage life and physiochemical characteristics of papaya. Amer. J. Agric. Biol. Sci. 3, 526-533.

MNFS \& R (Ministry of National Food Security and Research). 2016. Agricultural Statistics of Pakistan. Economic Wing, Islamabad, Pakistan. 
Nasir, M., Khan, A.S., Basra, S.A., Malik, A.U. 2016. Foliar application of moringa leaf extract, potassium and zinc influence yield and fruit quality of 'Kinnow' mandarin. Scientia Hort. 210, 227-235.

Naz, F., Haq, I.U., Asghar, S., Shah, A.S., Rahman, A. 2011. Studies on growth, yield and nutritional composition of different tomato cultivars in Battal valley of District Mansehra, Khyber Pakhtunkhwa, Pakistan. Sarhad J. Agric. 27, 569-571.
Nyamah, E.Y., Maalekuu, B.K., Oppong-skyere, D. 2012. Influence of different soil amendments on postharvest performance of tomato cv. Power (Lycopersicon esculentum Mill). J. Stored Prod. Postharvest Res. 3, 7-13.

Pedro, A.M., Ferreira, M.M. 2007. Simultaneously calibrating solids, sugars and acidity of tomato products using PLS2 and NIR spectroscopy. Anal. Chim. Acta. 595, 221-227.

Rai, G.K., Kumar, R., Singh, A.K., Rai, P.K., Rai, M., Chaturvedi, A.K., Rai, A.B. 2012. Changes in antioxidant and phytochemical properties of tomato (Lycopersicon esculentum Mill.) under ambient condition. Pak. J. Bot. 44, 667-670.

Sepat, N.K., Kumar, A., Yadav, J., Srivastava, R.B. 2012. Effect of integrated nutrient management on growth, yield and quality of tomato in Trans Himalayan. Annals Plant Soil Res. 14, 120-123.

Story, E.N., Kopec, R.E., Schwartz, S.J., Harris, G.K. 2010. An update on the health effect of tomato lycopene. Annu. Rev. Food Sci. Technol. 1, 189210.

Toor, R.K., Savage, G.P., Lister, C.E. 2006. Seasonal variations in the antioxidant composition of greenhouse grown tomatoes. J. Food Comp. Anal. 19, 1-10. 